\title{
PALOTÁS József
}

\section{A szakképzési iskolaszerkezet negyedszázada}

Elismerés illeti a Magyar Pedagógiai Társaság Szakképzési Kollégiumát és a Budapesti Műszaki Egyetem Tanárképző Központját a jubileumi konferencia megszervezéséért. Negyed század történelmi léptékben is korszaknak tekinthető, egy szakmai közösség számára pedig megkerülhetetlen alkalom a visszatekintésre és a kollegiális találkozásra. Nem csak a hétköznapi munka világa, hanem a döntéselőkészítés és döntéshozatal is drámai mértékben gyorsult fel a konferencia által átfogott huszonöt évben. A szakképzés iskolaszerkezete, a szakmastruktúra, valamint a tartalomszabályozás számos változáson ment keresztül az elmúlt negyedszázadban. Az átalakítások gyakoriságát a rendszer szereplői olykor nehezen követték, a döntések indokoltságáról és helyes irányáról szakmai viták, diskurzusok folytak és folynak ma is. A vitaindító előadásban a szakiskolai és szakközépiskolai (szakgimnáziumi) iskolaszerkezet változásainak vázlatos áttekintésére kaptamfelkérést a rendszerváltást követő szakképzési törvény megalkotásától napjainkig. Számos fogalmat át kellett tekinteni a visszatekintés során, mint a szakmai előkészítő és a szakmai alapozó oktatás, a szakmai orientáció és a szakmacsoportos alapozó oktatás, az „előrehozott” szakképzés, az „ágazati” szakközépiskola, szakgimnázium. Az áttekintés során a szabályozásból és annak módosításaiból indultam ki, elősegítendő a témában a szakmai diskurzus megkezdését. Meghatározóan a közoktatásról szóló törvény határozta meg a szakképzésben az iskolaszerkezetet a vizsgált időszakban, azonban 2011 és 2016 között a szakképzési törvényben szerepeltek a szakképző iskola típusok. Az 1990-es rendszerváltás óta eltelt közel három évtized egyik fő kérdése volt a magyarországi szakképzés iskolaszerkezetét érintően az évfolyamok száma, a közismereti és szakmai óraszámok aránya, az, hogy melyik évben kezdődjenek a szakképzési évfolyamok, megkezdődjék-e a szakképzés az alsóbb évfolyamokon, vagy csak szakmai illetve szakmacsoportos alapozás folyjék-e, így tolva későbbre a pályaválasztás lehetőségét és a szakképzési évfolyamokat. A történeti visszatekintés szakaszait azokhoz az évszámokhoz kötöttem, amikor az adott változásról szóló jogszabálymódosítás megjelent. Kívánok az olvasónak hasznos és gondolatébresztő időutazást, és bízom abban is, hogy a jövő döntéshozóinak segítséget nyújthatunk az értékek, eredmények tovább örökítéséhez, valamint a már egyszer tévútnak bizonyult modellek elkerüléséhez.

\section{3 - a rendszerváltást követő első reform}

A rendszerváltás előtti időszakból örökölt két éves szakiskolai illetve három éves szakmunkásképzési modellt az 1990-es években váltotta felmenő rendszerben az un. 2+2 évfolyamos modell. A szakképzés szerkezetét a rendszerváltás után megjelent közoktatásról szóló 1993. évi LXXIX. törvény határozta meg, ebben az évben született meg a szakképzési törvény is (1993. évi LXXVI. tv.), mely a szakképzési évfolyamokra volt irányadó.

A törvény értelmében a szakiskola a tankötelezettség megszűnése után készített fel szakmai vizsgára. Ekkor a tankötelezettség korhatára a 16. életév betöltése volt, tehát a 9-10. évfolyamon nem folyt szakképzés. A szabályozás értelmében a szakiskola a munkába álláshoz és önálló életkezdéshez szükséges ismereteket nyújtotta. A szakképzést megelőzően - az első szabályozás szerint még általános iskolai oktatás keretében - az általános múveltséget megalapozó kilencedik és tizedik évfolyam is elvégezhető volt, tehát a közoktatási törvény kvázi meghosszabbította az általános iskolai tanulmányokat. 
A szakközépiskolai képzés az 1993. évi közoktatási törvény értelmében 9-12. évfolyamok közötti szakaszt jelent, egyes esetekben 13. évfolyam is lehetséges volt. Ez azt jelentette, hogy a szakközépiskolában szakirányú nyelvi és más, a szakirányú képzést növelő osztályok voltak szervezhetők, akár indokolt esetben a 13. évfolyammal bővülve. A szakközépiskolai képzés céljaként az általános műveltség megalapozása mellett az érettségi vizsgára és a felsőfokú tanulmányok megkezdésére való felkészítést definiálta a jogalkotó. A szakképzési évfolyamokon - melyek a törvény értelmében az érettségi megszerzését, azaz a 12 . évfolyam elvégzését követően kezdődhettek meg - a szakmai vizsgára felkészítő nevelés és oktatás folyt. A középiskolai nevelés és oktatás szakasza a 12. évfolyammal fejeződött be. A szakközépiskola az utolsó középiskolai évfolyamot vagy az érettségi vizsgát követően készített fel a szakmai vizsgára.

A közoktatási és a szakképzési törvények megjelenése mellett fontos évszám 1993 a tartalomszabályozás szempontjából is, hiszen a korábbi szakmai jegyzékeket felváltotta az egységes Országos Képzési Jegyzék (OKJ) is. Az iskolarendszerű képzési szerkezethez igazodóan a szakmák jelentős részét csak a 10. vagy a 12. iskolarendszerű évfolyam elvégzését (utóbbi esetében érettségi megszerzését) követően lehetett megkezdeni, ugyanakkor a szakmák jelentős része iskolarendszeren kívüli felnőttképzésben is megszerezhető lett. Utóbbi azért is fontos, mert a rendszerváltást követő gazdasági átalakulással járó jelentős munkanélküliség kezelésében a felnőttképzés, mint aktív munkaerőpiaci eszköz nagy hangsúlyt kapott.

\section{6 - az első korrekció éve}

A közoktatási törvényt módosították az 1996. évi LXII. törvénnyel. Az 1996-os módosítások alapján 1998. szeptembertől felmenő rendszerben kellett bevezetni az új helyi tanterveket. A törvény definíciója szerint a szakiskolai képzés 9-10. évfolyamain az általános múveltséget megalapozó oktatás folyik, emellett a 9-10. évfolyamon szakmai elókészítő ismereteket is oktathatnak. 1996-ban tehát a 9-10. évfolyamok meghatározásában történik a fordulat, amíg az eredeti törvény szöveg szerint kizárólag közismereti oktatás folyik, a módosítás értelmében megjelenik a szakmai előkészítő ismeretek tartalma. A szakiskola a tankötelezettség megszűnése után (16. év), a szakképzési évfolyamokon készít fel szakmai vizsgára.

A szakközépiskolának a szabályozás értelmében négy középiskolai évfolyama van. A középiskolai évfolyamokon középiskolai nevelés és oktatás, annak befejezését követően a szakképzési évfolyamon szakképzés folyik. Az általános múveltséget megalapozó oktatás részeként a szakközépiskolában is megjelent a szakmai elókészítő ismeretek átadásának lehetősége. A szakközépiskola az utolsó középiskolai évfolyam elvégzéséhez, illetve középiskolai végzettséghez kötött szakképesítések körében készít fel szakmai vizsgára.

Ekkor született döntés született arról is, hogy a tankötelezettség korhatára az 1998/1999. tanévtől, azaz 1998. 09. 01-től, az általános iskola első osztályától felmenő rendszerben 18. életévre emelkedett. A törvénymódosítás rendelkezett arról is, hogy a Nemzeti Alaptanterv (NAT) bevezetésével összhangban a szakközépiskoláknak és a szakiskoláknak a közismereti és a szakmai elméleti tantárgyak oktatását át kellett szervezniük. Ezt oly módon kellett tenniük, hogy a szakképzés csak az iskola felsőbb évfolyamain folyhasson. A rendelkezések szerint 1998. szeptember 1-jétől a szakképzésben az oktatást szét kellett választani általános múveltséget megalapozó pedagógiai szakaszra és szakképesítés megszerzésére felkészítő pedagógiai szakaszra. Ettől az időponttól kezdődően szakképzés kizárólag a tankötelezettség megszűnését, az utolsó középiskolai évfolyamot, illetve az érettségi vizsgát követően volt indítható új, első szakképzési évfolyamon. 


\section{9 - az alapozó oktatás megjelenése}

A közoktatási törvény módosítása az 1999. évi LXVIII. törvénnyel történt meg. A szakiskolai képzési szerkezet definíciója ismét változott, mely szerint a szakiskolának 9-10. évfolyama és legalább két szakképzési évfolyama van. A 9-10. évfolyamokon általános múveltség megalapozása folyik, emellett megjelent a pályaorientáció, a szakmai előkészítő ismeretek oktatása és a szakmai alapozó oktatás is.

A szakközépiskolának a módosító rendelkezések értelmében érettségire felkészítő, általános múveltséget megalapozó négy középiskolai évfolyama van. A szakközépiskolai képzésben a 9. évfolyamtól kerettanterv szerinti szakmai orientáció, továbbá a 11. évfolyamtól elméleti és gyakorlati szakmacsoportos alapozó oktatás is folyhat. Látható tehát, hogy ezzel a korrekcióval a szakmai jellegű tartalmak már 9. évfolyamtól ismét megjelentek mind a szakiskolai, mind a szakközépiskolai képzésben. A szakmacsoportos alapozó oktatáshoz 2000-ben jelentek meg a kerettantervek, ezt követően a 2001/2002. tanévtől, tehát 2001. 09. 01-től lett felmenő rendszerben bevezetve.

A szakiskolai lemorzsolódás egyre égetőbb problémájára keresett szakmapolitikai válaszként jelent meg a szabályozásban a felzárkóztató oktatás lehetősége. A módosítás értelmében, ha az adott tanévben a tanuló a 16. életévét betölti, de nem fejezte be az általános iskola nyolcadik évfolyamát, a szakiskolában egy-két évfolyamos időtartamú felzárkóztató oktatásban vehet részt.

\section{3 - a kerettanterv ajánlások bevezetése}

A 2004/2005. tanévtől kellett alkalmazni a kerettanterv ajánlásokat, mely fogalmat a közoktatási törvényt módosító 2003. évi LXI. törvény vezette be a jogi szabályozásba. Az új rendelkezés célja az volt, hogy a Nemzeti Alaptantervben foglaltak teljesítését az oktatási miniszter által kiadott kerettantervek segítsék elő. Az iskola a Nemzeti Alaptanterv alapján a pedagógiai programjának részét képező helyi tantervet készít. Az iskola az oktatási miniszter által kiadott kerettantervek alapján is elkészíthette helyi tantervét, illetve a kerettantervet is beépíthette helyi tantervként a pedagógiai programjába, továbbá a NAT alapján készített helyi tantervek közül választhatott is. A középiskola a helyi tantervének elkészítéséhez figyelembe veszi az érettségi vizsga vizsgatárgyainak vizsgakövetelményeit is. Az érettségi vizsga részletes követelményeiről szóló 40/2002. (V. 24.) OM rendelet előző évben jelent meg. A kerettanterv ajánlásokat tartalmazott a szakiskolai és a szakközépiskolai oktatásra egyaránt. Szakiskolában a pályaorientációra, a szakmai előkészítő, szakmai alapozó oktatásra, továbbá az általános múveltséget megalapozó nevelés-oktatás és a pályaorientáció, a szakmai előkészítő, szakmai alapozó oktatás, illetve a szakmai elméleti és gyakorlati képzés időbeli tagolására, időkereteire, arányaira, továbbá szakközépiskolában a szakmai orientációra, az elméleti és gyakorlati szakmacsoportos alapozó oktatásra, továbbá az általános múveltséget megalapozó nevelés-oktatás és a szakmai orientáció, az elméleti és gyakorlati szakmacsoportos alapozó oktatás, illetve a szakmai elméleti és gyakorlati képzés időbeli tagolására, időkereteire, arányaira.

\section{7 - a küldő, fogadó iskolák a fővárosban}

Bár csak a fővárosban vezették be a térségi integrált szakképző központok létrehozásával összefüggő profiltisztítás céljából, a „küldő, fogadó” iskolák rendszere iskolaszerkezeti vonatkozásokat is jelentett az érintett iskolák számára. A közoktatási törvény módosításáról szóló 2007. évi LXXXVII. törvény tette lehetővé a „küldő, fogadó” iskolák feladatmegosztását. Az érintett iskolák a szakképzési feladataikat közös feladatellátás keretében szervezték meg. A csak szakképzési évfolyamokkal rendelkező iskola készítette fel egy, vagy több szakiskola, vagy szakközépiskola tanulóit a szakképzési évfolyam követelményeire. A küldő iskola szakképzési évfolyamainak száma csökkenthető, valamint szakképzési évfolyam nélkül is múködhetett. A szakiskola, illetve szakközépiskola tanulója a szakmai vizsgára felkészítő iskola szakképzési évfolyamába - az átvételre vonatkozó rendelkezések szerint - 
ugyanazokkal a feltételekkel léphetett át, mintha a tanulmányait a küldő iskolában folytatná tovább. A tanulmányok szakképzésbe történő beszámítása érdekében az iskolák összehangolták pedagógiai programjaikat.

\section{9 - az előrehozott szakképzés}

Az "elörehozott” szakképzés a közoktatási törvényt módosító 2009. évi XLIX. törvény alábbi rendelkezései szerint indíthatta útjára mintegy másfél évtized elteltével ismét a három évfolyamos szakiskolai képzést. A szakiskolának - a szabályozásban meghatározott kivételekkel - kilencediktizedik és az adott szakképesítés megszerzéséhez szükséges szakképzési évfolyama van, a szakképzési évfolyamok számát az Országos Képzési Jegyzék határozza meg. Ha a szakiskola több szakképesítés megszerzésére készít fel, a szakképzési évfolyamok száma - a felkészítési időtől függően - az egyes szakképzésekben eltérhet egymástól. A szakiskola 9-10. évfolyamán általános múveltséget megalapozó nevelés-oktatás, továbbá a kötelező óra legfeljebb 50\%-ában pályaorientáció, gyakorlati oktatás, szakmai alapozó elméleti és gyakorlati oktatás folyik, valamint - az OKJ szerinti - elméleti és gyakorlati szakmacsoportos alapozó oktatás is folyhat. A gyakorlati oktatást iskolai tanmúhelyben kell megszervezni. A szakképzési évfolyamokon az OKJ-ban meghatározott, a középiskola utolsó évfolyamának befejezéséhez vagy az érettségi vizsga letételéhez nem kötött szakképzettségek körében folyhat szakképzés. A szakképzési évfolyamokon a tanuló a szakmai vizsgára készül fel. Látható tehát, hogy ezzel a módosítással visszakerült a 9-10. évfolyamokra a pályaorientáció és a szakmai, illetve a szakmacsoportos alapozó oktatás mellett a gyakorlati képzés is.

\section{1 - az új törvények}

A 2011 év új köznevelési és szakképzési törvények megalkotását hozta el az oktatás világában. Ekkor a szakképzési iskolaszerkezet szabályozása átkerült a szakképzési törvénybe. Az új típusú, „ágazati” szakközépiskolai képzést a 2013/2014. tanévtől, tehát 2013. 09. 01-től felmenő rendszerben vezették be. Az ágazati szakközépiskolában a Nemzeti Alaptantervre épülő kerettantervek szerinti közismereti oktatással párhuzamosan a 9-12. évfolyamon az ágazathoz tartozó érettségi végzettséghez kötött, a szakképesítések közös tartalmi elemeit magában foglaló szakmai elméleti és gyakorlati oktatás folyik az ágazati szakképzési kerettanterv szerint. Tehát a szakképesítés megszerzése a 12. évfolyam után lehetséges, de annak előkészítése már benne van a 9-12. évfolyam tartalmában. Az adott szakközépiskolai ágazatra előírt szakmai érettségi vizsgatárgy követelményei szerint az ágazati szakközépiskola felkészít a kötelező szakmai érettségi vizsgatárgyból tehető érettségi vizsgára. A szakközépiskola a szakmai érettségit szerzett tanulóját szakképzési évfolyamán felkészíti legalább egy, az ágazathoz tartozó szakképesítésre.

A szakiskola szakképzési évfolyamain, azaz 9-12. évfolyamokon a szakképzési kerettanterv szerinti szakmai elméleti és gyakorlati oktatás folyik a közismereti oktatással párhuzamosan. A szakiskolai képzésbe alapfokú iskolai végzettséggel vagy Köznevelési Hídprogram elvégzésével lehetett bekapcsolódni.

\section{6 - új megnevezések, változó szerkezet}

A 2016/2017-es tanévtől bevezetett változások alapvetően érintették az iskolatípusok elnevezését és a szakképzési szerkezetet is. A szakiskola fogalma innentől a korábbi speciális szakiskola iskolatípust jelöli, mely a többi tanulóval együtt haladásra képtelen, sajátos nevelési igényú gyermekeket a hozzájuk igazodó tanterv alapján juttatja el részképesítés és akár szakképesítés megszerzésén keresztül az önálló életvezetés lehetőségéhez. A szakközépiskola fogalmával a korábbi szakiskolát jelöljük azzal a szerkezeti változással, hogy a hároméves szakmai képzés elvégzését és a szakmai bizonyítvány megszerzését követően két közismereti évfolyam érettségire készíti fel a tanulókat úgy, hogy a négy kötelező érettségi tantárgy mellett a szakmai vizsga megszerzésével mentesülnek az 
ötödik, kötelezően választandó érettségi vizsgatárgy alól. Ez a szakközépiskolai képzés tehát a 3+2 évfolyamos szerkezetre iskoláz be. A szakgimnázium megnevezés a korábbi szakközépiskola típust fedi le azzal, hogy szintén szerkezeti változásokat is jelent. A szakgimnázium 2016/2017. tanévi bevezetésekor az volt a koncepció, hogy a tanuló az érettségi mellett az Országos Képzési Jegyzéken szereplő szakképesítést is szerez, melyet 2018-ban annyiban korrigáltak, hogy a 12. évfolyamig megszerezhető szakképesítés választhatóvá vált 10. évfolyamon, tehát annak megszerzése nem kötelező. Így a szakgimnáziumi képzés jelenleg felkészít az érettségire, a szakmai érettségire, a szakgimnáziumi ágazatnak megfelelő szakképesítés megszerzésére, mely 13. szakképzési évfolyamon fejeződik be, és 11-12. évfolyamon választható tartalmak szerint differenciálhatóak a képzési tartalom belső arányai attól függően, hogy a tanuló szeretne-e érettségi mellett mellékszakképesítést szerezni, vagy inkább például a közismereti óraszámból szeretne többet, felkészülve az érettségire és a továbbtanulásra.

A nemzeti köznevelésről szóló 2011. évi CXC. törvény módosításáról szóló 2015. évi LXV. törvény vezette be a szakgimnázium fogalmát, egyúttal a szakképzési iskolaszerkezet szabályozását visszahelyezte a köznevelésről szóló törvénybe. A szakgimnázium tehát a 2016 évi jogalkotás szerint szakmai érettségi végzettséget adó érettségire és ehhez kapcsolódó szakképesítés megszerzésére, szakirányú felsőfokú iskolai továbbtanulásra, szakirányú munkába állásra készít fel. A szakgimnázium általános múveltséget megalapozó négy középiskolai évfolyammal és szakképzési évfolyamokkal rendelkezik, ahol szakmai elméleti és gyakorlati oktatás folyik.

Az új típusú szakközépiskolának öt évfolyama van, ebből három 3 szakképzési évfolyam, melyek a szakképesítés megszerzéséhez szükséges közismereti képzést, valamint szakmai elméleti és gyakorlati oktatást tartalmazzák, a sikeres szakmai vizsgát követheti a tanuló választása esetén két, az érettségi vizsgára felkészítő évfolyam, mely közismereti képzést jelent.

Ezzel a törvénymódosítással jelent meg a szakképzési hídprogram, e képzési típus két évfolyamos, záróvizsgával fejeződik be, kimenete az alapfokú iskolai végzettséget igazoló tanúsítvány, valamint a részszakképesítés. Alapfokú iskolai végzettség hiányában a szakközépiskolába történő felvétel feltétele a tizennegyedik életév betöltése, és a szakközépiskolában szervezett Szakképzési Hídprogram szerinti tanév teljesítése.

\section{8 - a szakgimnázium korrekciója}

A szakgimnáziumi képzési forma korrekcióját a nemzeti köznevelésről szóló 2017. évi CXCII. törvény szabályozta. A szakgimnáziumban a középfokúnevelés-oktatás szakasza a 9. évfolyamon kezdődik és a 12. évfolyam végén fejeződik be. A szakképesítés megszerzésére felkészítő szakasz: 13. vagy a 14. évfolyamon fejeződik be. A szakgimnázium érettségi, szakmai érettségi, mellék-szakképesítés, szakképesítés megszerzésére valamint továbbtanulásra készít fel. A szakgimnáziumban OKJ ágazatokban tehető szakmai érettségi vizsga, valamint a tanuló választása szerinti, a szakképzési törvényben definiált mellék-szakképesítés, továbbá az OKJ-ben meghatározott, az adott szakgimnáziumi ágazathoz tartozó szakképesítés szerezhető. Az szakgimnáziumi képzés tartalma a912. évfolyamon magában foglalja az adott ágazathoz tartozó szakképesítések közös tartalmi elemeit, a szakmai érettségi vizsga ágazatához tartozó szakképesítés tartalmi elemeit,tanuló választása alapján a mellék-szakképesítés tartalmi elemeit, továbbá egyéb, a szakképzési kerettantervben meghatározott választható tartalmat a közismereti képzés mellett. A mellék-szakképesítés tartalmi elemeinek tanulásáról a választás lehetősége a szakgimnáziumi tanulmányokat a 2016/2017. tanévben kilencedik évfolyamon, valamint a 2017/2018. tanévben kilencedik évfolyamon megkezdett tanulókra is kiterjed. 


\section{Kihívások}

Korunk szakképző iskolája és a szakképzés egyéb érdekeltjei számos kihívással kell szembenézzenek, míg a munkaerőpiac szereplői képzett, vagy legalább képezhető munkaerő rendelkezésre állásának követelményét támasztják a szakmai oktatással szemben. A korai iskolaelhagyás (lemorzsolódás) jelensége mögött komplex társadalmi okok állnak, melyek megjelenése komoly kihívások elé állítja az iskolai alkalmazkodóképességet. Az iskolát elhagyó tanuló egyaránt veszteség a család, az iskola, és a munkáltató számára, így a lemorzsolódás megelőzése, csökkentése kiemelt prioritás szakmapolitikai szinten is. Ábránk a korai iskolaelhagyók átlag adatait tartalmazza, mely mutatók a szakképzésben sokkal rosszabb arányokat mutatnak.

Kihívás elé állítja a szakképzést a negatív demográfiai trend, a beiskolázható gyermekek számának csökkenése fokozottabb pályaorientációs tevékenységet és beiskolázási aktivitásokat kíván meg mind az iskolától, mind a leendő munkáltatóktól. A szakképző iskolára - és nemritkán annak duális partnereire - hárul azoknak a tanulóknak felzárkóztatási szükségszerúsége, akik komoly alapkészség hiányosságokkal kerülnek be a középfokú szakmai oktatás intézményeibe. Munkáltatói fórumokon gyakran hangzik el a szakmai gyakorlati oktatást végző munkáltatók részéről, hogy például matematikai alapmúveletek gyakorlását is végzik annak érdekében, hogy a tanuló a gyakorlati oktatásban való részvételre alkalmassá váljék. Ugyanígy meg kell küzdenie az iskolának és a gyakorlati képzést folytató szervezeteknek a tanulói motiváció hiányosságaival, ami emberi kihívást jelent, egyúttal minden tanuló megtartása komoly eredményt is. A tanulószerződések száma ugyanakkor tíz éves távlatban - egy kisebb, 2012-2013 időszakban látható visszaeséstől eltekintve folyamatos emelkedést mutat.

A szakképzés rendszerszintű kihívásai között megjelenik a technológiai innováció, a digitalizáció. A munkaerőpiac, ugyanakkor a célcsoport is szegmentált és sokszínü, ami differenciált megközelítést igényel mind makro- mind mikroszinten a szakképzési rendszer érdekeltjeitől. A szakmai tanárok, szakoktatók utánpótlásával is foglalkozni kell, hiszen a keresett szakterületeken a versenyszféra béreivel többnyire nem versenyképes az iskola, de igaz ez olyan fontos műszaki területeket alapozó közismereti tárgyakat oktató tanárokra is, mint a fizika, matematika, informatika. Az európai folyamatok között meg kell említeni a validáció azaz a nem formális és informális úton szerzett kompetenciák elismerésének problémakörét, mely egyebek mellett egy adekvát alternatíva lehet a munkaerőhiány orvoslására.

\section{Összegzés}

A szakképzés szerkezete, a szakmastruktúra, valamint a tartalomszabályozás számos változáson ment keresztül az elmúlt negyedszázadban. Minden átalakításnak figyelembe kell vennie azonban, hogy a megelőző korszakok törekvéseinek eredményeit, értékeit integrálva - okulva azok hibáiból, hiányosságaiból - a tanulók egyéni képességeinek kibontakoztatását, a vertikális és horizontális átjárhatóságot, a hátránykompenzációt és tehetségfejlesztést, valamint a munkaerőpiacnak adekvát kimenetet, a továbbtanulás lehetőségét együttesen kell biztosítania a szakképzés rendszerének, mert ez szolgálja a tanulók, a munkáltatók, a szülők, így a társadalom érdekeit. 